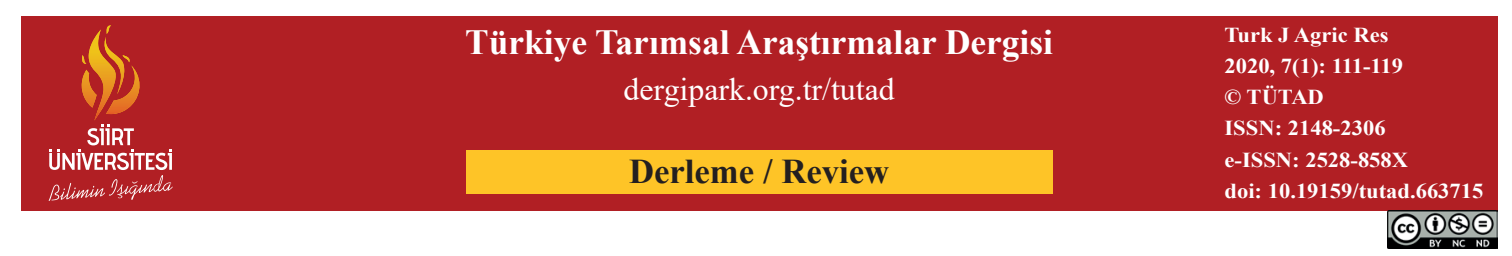

\title{
Kenevir (Cannabis sativa L.) Bitkilerinde Görülen Virüs Kaynaklı Hastalıklar
}

\author{
Mehmet Ali ŞEVIK* \\ Ondokuz Mayls Üniversitesi, Ziraat Fakültesi, Bitki Koruma Bölümü, Samsun, TÜRKIYYE
}

\begin{tabular}{l}
\hline Geliş Tarihi/Received: $23.12 .2019 \quad$ Kabul Tarihi/Accepted: 16.02 .2020 \\
\hline ORCID ID \\
(iD) orcid.org/0000-0002-8895-7944 \\
*Sorumlu Yazar/Corresponding Author: malis@omu.edu.tr
\end{tabular}

Öz: Kenevir (Cannabis sativa L.), Cannabaceae familyası Cannabis cinsi içerisinde yer almaktadır. C. sativa'nın bir varyetesi olan endüstriyel kenevir (C. sativa ssp. vulgaris L.) kültürü yapılan önemli bir endüstri bitkisidir. Endüstriyel kenevir insanlık tarihinin en eski bitkisel ham madde kaynaklarından birisi olarak bilinmektedir. Kenevir; tohum, yağ, giysi, ip, kâğıt, yalıtım malzemesi, kozmetik ürünler, biyolojik olarak parçalanabilen plastikler, inşaat malzemesi, reçine, yakıt vb. gibi çeşitli ürünler elde etmek amacıyla yetiştirilmektedir. Kenevir çevre şartlarına, hastalık ve zararlılara karşı oldukça hassastır. Olumsuz çevre koşullarında bitkiler hastalıklara daha yatkın hale gelmektedir. Kenevir bitkilerinde 100'den fazla mikroorganizma (fungus, bakteri, virüs vd.) hastalık olușturabilmektedir. Yapılan birçok çalıșmada; kenevir çizgi virüsü (HSV), kenevir mozaik virüsü (HMV), yonca mozaik virüsü (AMV), hıyar mozaik virüsü (CMV) ve arabis mozaik virüsü (ArMV)'nün kenevir ceșitlerinde hastalıklara neden olduğu rapor edilmiștir. Ayrıca tütün mozaik virüsü (TMV), tütün halkalı leke virüsü (TRSV), tütün çizgi virüsü (TSV), domates halkalı leke virüsü (TomRSV), taflan halkalı leke virüsü (ERSV), karaağaç mozaik virüsü (EMV), tilkikuyruğu mozaik virüsü (FMV) kenevir bitkilerinden izole edilmiștir. Son yıllarda kenevir virüsleri üzerinde yapılan çalışmalarda ise, şekerpancarı tepe kıvırcıklık virüsü (BCTV) ve marul kloroz virüsü (LCV)'nün kenevir bitkilerinde enfeksiyon gerçekleştirdiği rapor edilmiştir.

Anahtar Kelimeler: Cannabis, kenevir, hastalık, virüs, vektör

\section{Virus-Induced Diseases in Hemp (Cannabis sativa L.) Plants}

\begin{abstract}
Hemp (Cannabis sativa L.) belongs to Cannabis genus in Cannabinaceae family. Industrial hemp (C. sativa var. vulgaris L.), a variant of the $C$. sativa, is an important industrial crop. Industrial hemp is one of the oldest raw material resource crops know to humans. Hemp is cultivated to produce a vast variety of products such as hemp seeds, hemp oil, clothing, rope, paper, insulation, cosmetics, biodegradable plastics, construction material, resin, fuel, etc. Hemp is very sensitive to environmental conditions, diseases, and pests. Plants are more susceptible to diseases in adverse environmental conditions. More than 100 microorganisms (fungi, bacteria, virus, etc.) can cause disease in cannabis. In many studies conducted; hemp streak virus (HSV), hemp mosaic virus (HMV), alfalfa mosaic virus (AMV), cucumber mosaic virus (CMV) and arabis mosaic virus (ArMV) have been reported to cause diseases in hemp varieties. Also, tobacco mosaic virus (TMV), tobacco ringspot virus (TRSV), tobacco streak virus (TSV), tomato ringspot virus (TomRSV), eunoymous ringspot virus (ERSV), elm mosaic virus (EMV), and foxtail mosaic virus (FMV) are isolated from hemp plants. In recent years, studies on cannabis viruses have reported that beet curly top virus (BCTV) and lettuce chlorosis virus (LCV) infect cannabis plants.
\end{abstract}

Keywords: Cannabis, hemp, disease, virus, vector 


\section{Giriş}

Kenevir (Cannabis sativa L.), Urticales takımı Cannabaceae familyası Cannabis cinsi içerisinde yer alan tek yıllık bitki türüdür. Kültürü yapılan endüstriyel kenevir 120-450 cm aras1 bir yükseklikte yetişebilen bir alt ( $C$. sativa ssp. vulgaris L.) varyetedir (Aytaç ve ark., 2017). Kenevir, en eski bitkisel ham madde kaynaklarından birisi olarak bilinmektedir (Andre ve ark., 2016; Dingha ve ark., 2019).

Kenevir liflerinden ve saplarından, tohum, yaprak ve çiçeklerinden yararlanılan çok yönlü bir bitkidir. Kâğıt, biyoyakıt, ilaç, kozmetik ürünler, sabun, kumaş, otomotiv sektörü ve daha birçok alanda kullanılmaktadır (Grabowska ve ark., 2009; Aytac, 2018).

Kenevir insanlık tarihinde tohumu ve lifleri için yetiştirilen ilk kültür bitkilerinden birisi olarak kabul edilmektedir (Cherney ve Small, 2016). Arkeolojik çalışmalar sonucunda M.Ö. 8000 yıllarına ait kenevirden üretilmiş kumaş kalıntılarına rastlanmış; M.Ö. 1500'lü yıllarda Anadolu'da kenevir üretimi yapıldı̆̆ edilmiştir (Gizlenci ve ark., 2019).

Dünya genelinde şu anda Çin, Kanada ve pek çok Avrupa ülkesinde, çiftçilerin endüstriyel kenevir yetiştirmelerine izin verilmektedir (Salentijn ve ark., 2015). Türkiye'de ise 26 Eylül 2016 tarihinde resmi gazetede yayımlanan yönetmeliğe göre; Amasya, Antalya, Bartın, Burdur, Çorum, İzmir, Karabük, Kastamonu, Kayseri, Kütahya, Malatya, Ordu, Rize, Samsun, Sinop, Tokat, Uşak, Yozgat ve Zonguldak olmak üzere 19 ilde izin alınması koşulu ile kenevir üretimi yapılabilmektedir. Uzun yıllardır Anadolu coğrafyasında üretilen kenevir (Aytaç ve ark., 2018a), yoğun olarak Samsun ili Vezirköprü ilçesinde üretilmektedir (Gizlenci ve ark., 2019).

Kenevir çevre koşularına oldukça hassas bir bitkidir (Aytaç ve ark., 2018b). Kenevir üretimi ve verimini etkileyen birçok faktör bulunmaktadır (McPartland, 1996). Çok sayıda hastalık (virüs, bakteri, fungus, fitoplazma, viroid) etmeni ve zararlı (böcek, akar, nematod) türü kenevir üretimini etkilemektedir (Bakro ve ark., 2018).

Kenevir bitkisinde çok sayıda viral etmen enfeksiyon gerçekleştirebilmekte ve verimi olumsuz yönde etkileyebilmektedir. Bu makalede kenevir bitkilerinde sorun oluşturabilecek önemli bazı viral etmenlerin tanımı, belirti, bulaşma ve yayılma yolları, mücadele yönetmeleri kısaca açıklanarak, muhtemel kayıları önleme yolları hakkında bilgiler sunulmuştur.

\section{Kenevirde Görülebilen Bazı Viral Etmenler}

Bitki virüs etmenleri sebze ve meyve başta olmak üzere, dünya çapında kültürü yapılan bitkilerde oldukça yaygındır ve bitkisel üretim için ciddi bir tehdit oluşturmaktadırlar (Soosaar ve ark., 2005). Çeşitli kültür bitkilerinde önemli hastalıklara ve verim kayılarına yol açabilen 21 familyaya ait çok sayıda viral etmen bulunmaktadır (King ve ark., 2012; Hull, 2014). Ayrıca, virüsler çok sayıda yabani otsu ve odunsu bitkide enfeksiyonlara neden olabilmektedir. Her geçen gün yeni viral etmenler belirlenmektedir. Yeni ortaya çıkan ve bitkileri etkileyen hastalıkların büyük bir kısmını viral kaynaklı etmenler oluşturmaktadır (Anderson ve ark., 2004).

Kenevir genelde tek sarmal RNA'ya sahip virüsler tarafından enfekte edilmektedir. Enfeksiyondan sonra virüslerin bitkide engellenmesi neredeyse imkânsız hale gelmektedir. Sistemik olarak yaprak, gövde, polen ve tohumlar dâhil olmak üzere tüm bitki dokularına virüs yayılabilmekte, kenevir bitkilerinde şiddetli simptomlara (Şekil 1) ve verim kayiplarına neden olabilmektedirler. Nadiren de olsa bitki ölümlerine de yol açabilmektedir (McPartland ve ark., 2000). Bitkilerde enfeksiyonlara neden olan virüslerin büyük çoğunluğu konukçudan konukçuya vektörler aracılığı ile taşınmaktadır (Whitfield ve ark., 2015).

Çok sayıda virüs kenevir bitkilerinde enfeksiyon oluşturabilirken, beş viral etmen yaygın olarak görülmektedir. $\mathrm{Bu}$ sinırlı enfeksiyonun nedeninin kenevir bitkisinin virüs inaktive edici tetrahidrokanabinol (THC) içeriğinden kaynaklanmış olabileceği bildirilmiştir (Lancz ve ark., 1990). Ayrica kenevirde antiviral aktiviteye sahip terpenoidler (limonene, $\alpha$-pinene) ve flavonoidleri (apigenin, luteolin, quercetin) bulunmaktadır (Che, 1991).

Kenevir çizgi virüsü (HSV), kenevir mozaik virüsü (HMV), yonca mozaik virüsü (AMV), hıyar mozaik virüsü (CMV) ve arabis mozaik virüsü (ArMV) kenevir bitkilerinde daha yaygın görülen virüsler arasında yer almaktadır (Ranalli, 1999).

\subsection{Kenevir çizgi virüsü (HSV)}

HSV ilk olarak Almanya'da tanılandiktan sonra farklı ülkelerde (İtalya, Çekya, Rusya, Macaristan vd.) farklı araştırıcılar tarafından tespit edilmiştir (Righetti ve ark., 2018).

Virüsün yaprak belirtileri soluk yeşil bir kloroz olarak başlar. Yaprak simptomları damarlar 

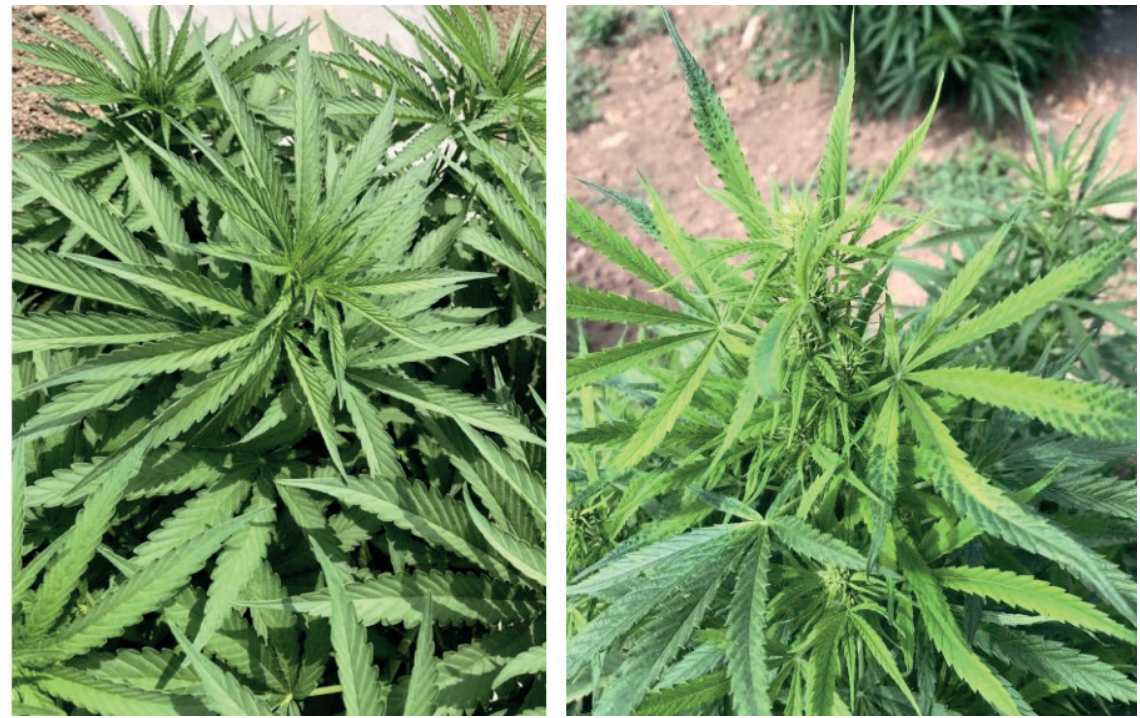

Şekil 1. Arazide sağlıklı (solda) ve virüs ile enfekteli (sağda) kenevir bitkisinin genel görünümü (Giladi ve ark., 2020)

arasında sarı çizgiler şeklinde görülür, sonrasında yaprak kenarları kırışır, yaprak uçları yukarı doğru kıvrılır (Şekil 2). Bu tür belirtilerin kenevir çeşitlerinde yaygın olarak görüldüğünü üreticiler tarafından bildirilmektedir (Righetti ve ark., 2018). Bazen kahverengi nekrotik lekeler ortaya çıkar, yaşlı yaprakların kenarlarında ve uçlarında lekeler oluşur. Virüs enfekteli bitkinin genelinde olarak solgunluk benzeri (Şekil 3) bir görünüm almasına neden olur (McPartland, 1996).

Virüsün yayılmasında vektör türlerin büyük önemi vardır. Kenevir çizgi virüsünün en önemli vektörü ise kenevir afiti Phorodon cannabis türüdür (Schmidt ve Karl, 1970). Virüs enfekteli bitkilerin tohumları ile nesilden nesile aktarılabilmektedir. Enfeksiyondan veya inokulasyan sonra altı gün içinde bitkilerde virüs belirtisi gözlenebilmektedir. Erkek kenevir bitkilerinin, dişi kenevir bitkilerine göre virüse karşı daha hassas olduğu bildirilmiştir. Hastalıklı bitkilerde bodurluk görülür ve lif veriminde ve tohum üretiminde azalmalara neden olur (McPartland ve ark., 2000). Bu nedenle verim kayıpların önlenmesi açısından virüsün bulaşma ve yayılma yollarının bilinmesi ve mücadele edilmesi oldukça önem arz etmektedir.

\subsection{Yonca mozaik virüsü (AMV)}

Kenevir bitkisini de enfekte edebilen AMV, 1931 yilında ilk olarak rapor edildikten sonra, en önemli viral etmenler arasında yer almıştır (Parrella, 2000). AMV, dünya çapında en yaygın virüslerden birisidir ve oldukça geniş konukçu dizisine sahiptir (Hughes ve Odu, 2003). Bu virüs çok sayıda otsu ve odunsu bitki türünü doğal olarak enfekte edebilmektedir (Xu ve Nie, 2006).
Virüsün 71 familyadan 700'den fazla bitki türünde enfeksiyon gerçekleştirdiği bildirilmiştir (Edwardson ve Christie, 1997). Schmidt ve Karl (1970) tarafından Almanya'da kenevir bitkilerinde AMV'nin doğal olarak bulunduğu saptanmıştır.

Bromoviridae familyası Alfamovirus cinsi içersinde yer alan AMV, 18 nm genişliğinde 18-60 nm uzunluğunda basiliform yapıda partiküllere sahiptir. AMV genomu pozitif-sense tek sarmal RNA içermektedir (Hughes ve Odu, 2003). Virüs farklı patojenisiteye sahip çok sayıda doğal varyantlara sahiptir (Al-Saleh ve Amer, 2013). Virüsün belirtisi konukçu bitki türüne göre değişkenlik göstermekle birlikte, genellikle yapraklarda mozayik, yapraklar boyunca klorotik çizgiler veya damarlar arasında kloratik lekeler, genç yapraklarda hafif kıvrılma şeklinde belirtilere neden olabilmektedir (Kegler ve Spaar, 1997).

AMV; vektör, tohum, aşı, küsküt ile ve mekaniksel olarak farklı bitki türlerinde taşınabilmektedir. Ancak virüsün taşınma ve yayılmasında en önemli rolü yaprak bitleri oluşturmaktadır. Virüs çok sayıda afit türü ile nonpersistent olarak taşınabilmektedir (Jeffries, 1998). En az 14 afit türü tarafından taşınabilirken, en önemli vektör türleri arasında; Myzus persicae, Acyrothosiphon pisum, A. Euphorbiae, A. craccivora, A. gossypii, Macrosiphoniella sanborni yer almaktadır (Jaspars ve Bos, 1980).

\subsection{Hıyar mozaik virüsü (CMV)}

CMV, Bromoviridae familyası Cucumovirus grubunun tip üyesidir. CMV, ilk olarak hıyar bitkisinde rapor edildikten sonra, dünya çapında yaygın bir virüs olarak bilinmektedir (Kumari ve ark., 2013). CMV, yaklaşık olarak 29-30 nm 


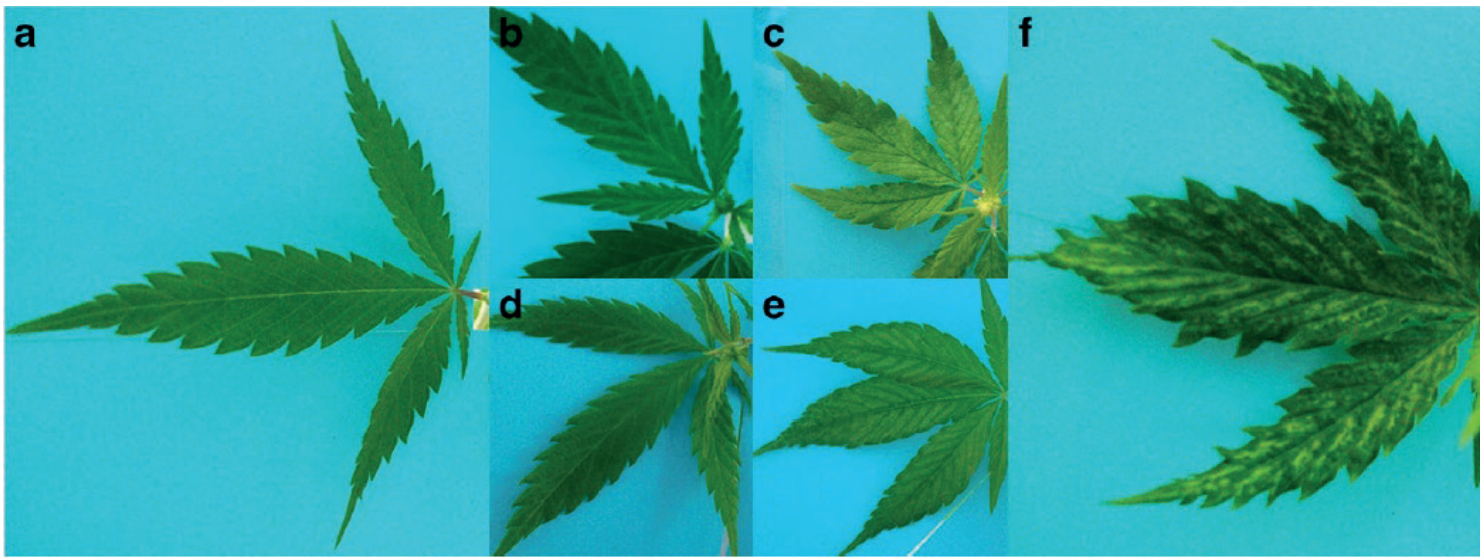

Şekil 2. Virüsün kenevir bitkisinde oluşturduğu bazı belirti süreçleri. a) sağlıklı b)damarlar arası sarı lekeler, c) damarlar arası kloroz, d) yaprak uçlarında kıvırcıklık, e) yaprak uçlarında yukarı kıvrılma, f) tüm yaprak yüzeyinde semptomların yayılması (Righetti ve ark., 2018)
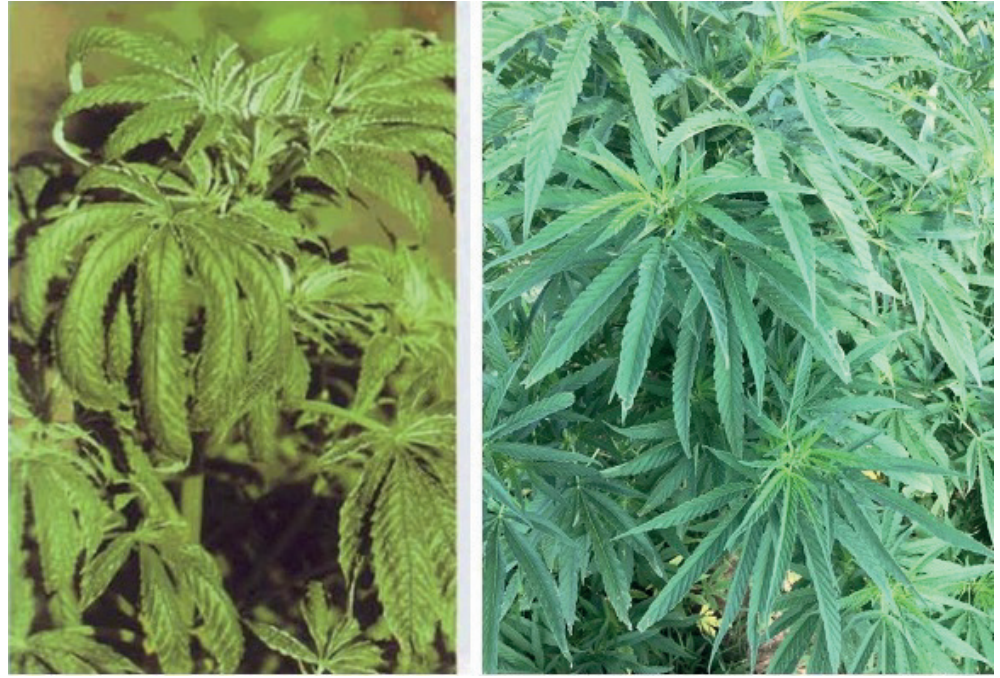

Şekil 3. HMV'in kenevir bitkisinde oluşturduğu belirti (solda) ve sağlıklı (sağda) kenevir bitkisi (McPartland, 1996)

çapında izometrik şekilli, üç parçalı (+) ssRNA genomuna sahiptir (Palukaitis ve Garcia-Arenal, 2003).

CMV, 100 'den fazla familyada 1.200 'den fazla bitki türünde enfeksiyonlar oluşturabilme yeteneğindedir (Zitter ve Murphy, 2009; Ouedraogo ve ark., 2019). Virüs sebze, meyve, süs bitkileri ve yabancı otlarda çok çeşitli simptomlar oluşturan oldukça geniş konukçu dizisine sahiptir (Palukaitis ve ark., 1992, Zitter ve Murphy, 2009). Virüsün konukçuları arasında kenevir bitkisi de yer almaktadır. Hıyar mozaik virüsünün kenevir bitkisi yapraklarında benekli mozaik (mottle) simptomuna neden olduğu bildirilmiştir (Schmidt ve Karl, 1970). Enfekteli bitkilerin özellikle genç yapraklarında yaprak yüzeyinin tamamı açık yeşil desenler ile kaplanabilmektedir (Kegler ve Spaar, 1997).
CMV tohum, vejetatif üretim materyalleri, küsküt, mekaniksel olarak taşınabilirken (Gallitelli, 2000; Palukaitis ve Garcia-Arenal, 2003); en önemli taşınma ve yayılma yollarının başında ise, vektör böcekler (yaprak biti) gelmektedir. CMV, 80'den fazla yaprak biti türü ile non-persistent olarak taşınabilmektedir (Palukaitis ve ark., 1992). Virüs, çok sayıda farklı yaprak biti türü tarafından kolayca taşınabilirken; en önemlileri arasında, Myzus persicae, Aphis gossypii, A. fabae ve Acyrthosiphon pisum yer almaktadir (Gildow ve ark., 2008).

CMV'nin bitkilerde neden olduğu verim kayıpları bitkiden bitkiye, yıldan yıla, bölgeden bölgeye değişsebilmektedir. Bazı bölgelerde virüsten kaynaklı verim kayıları \% 100'e ulaşabilmektedir (Gallitelli, 2000). Dünyada en yaygın ilk 10 virüs arasında yer alan hıyar mozaik 
virüsünün neredeyse her yıl yeni bir konukçusu tanılanmaktadir (Scholthof ve ark., 2011). Bu nedenle bulaşma ve yayılmasını (tohum, afit vd.) önleyici tedbirlerin alınması, dayanıklı/toleranslı çeşitlerin kullanılması ve diğer mücadele yöntemlerin uygulanması son derece önemli olacaktır.

\subsection{Yonca mozaik virüsü (ArMV)}

Yonca mozaik virüsü (ArMV; cins Nepovirus, familya Comoviridae), $30 \mathrm{~nm}$ çapında izometrik şekilli partiküllere sahiptir. Virüs çok sayıda önemli bitki türünde enfeksiyon gerçekleştirebilmektedir (Anonymous, 2002). Virüsün 28 familyadan 93 türü enfekte edebildiği rapor edilmiştir (Schmelzer, 1963). Çok sayıda kültür ve yabani bitki türlerinin konukçusu olduğu bilinmektedir. Virüs enfekteli bitkilerde yaprak kıvırcıklığı benekli mozayik, şekil bozukluğu, cüceleşme gibi şiddetli simptomlara neden olabilmektedir (Kominek ve ark., 2003). Virüsün konukçuları arasında kenevir bitkisi de yer almaktadır. ArMV, kenevir bitki yapraklarında açık yeşil/sarı lekeler, çizgiler şeklinde simptomlara neden olmaktadır (Schmidt ve Karl, 1969). ArMV; Avrupa, Asya, Afrika, Amerika ve Okyanusya kıtasında pek çok ülkede tespit edilmiştir (Anonymous, 2002).

Virüsün en önemli taşınma ve yayılma yolları arasında, vektörler ve çoğaltım materyalleri bulunmaktadır. ArMV, kısa mesafelerde toprakta bulunan nematodlar (Xiphinema spp.) ile taşınırken, uzak mesafelere tohum başta olmak üzere bulaşı üretim materyalleri ile olabilmektedir (Kominek ve ark., 2003). Bu nedenle mücadelesinde, yetiştiricilikte temiz üretim/çoğaltım materyallerinin kullanılması, vektör nematot içermeyen üretim alanlarında yetiştiricilik yapılması, toprak fumigasyonu ve diğer önlemlerin alınması hastalığın etkisinin azaltılmasında ve yayılmasının engellenmesi bakımından oldukça önemli olacaktır (Thresh ve Ormerod, 1989).

\subsection{Kenevir mozaik virüsü (HMV)}

Eski kaynaklar, kenevir mozaik virüsünün kenevir bitkisini enfekte edebildiğini bildirmektedir. Ancak bu virüs hakkında fazla detaylı bilgi bulunmamaktadır. Etmenin CMV gibi Cucumovirus veya ArMV, TRSV ve TomRSV gibi bir Nepovirus olabileceği bildirilmiştir (McPartland ve ark., 2000).

Romanya'da virüsün başlangıçta sarı benekler, klorotik lezyonlar olarak başlayıp sonradan nekrotik hale gelerek ve lezyonlar birleşerek sonunda bütün yaprağın solması şeklinde belirtiler oluşturduğu belirlenmiştir. Çekya'da kenevirde virüsün enasyon belirtisine (Blattny ve ark., 1950), Pakistan'da ise mozayik, yaprak kıvırcıklığı, tepe kıvırcıklığı ve uç yapraklarda küçülme şeklinde farklı belirtilere neden olduğu bildirilmiştir (Ghani ve Basit, 1975).

Virüsün taşınma ve yayılmasında; üretim materyalleri (tohum), vektör türleri sera beyazsineği ( $T$. vaporariorum), şeftali yaprak biti (M. persicae) ve soğan tripsi (T. tabaci) etkili olmaktadır (McPartland, 1996). Yine aynı şekilde Hemp mosaic virus'ünün en önemli vektörü kenevir afiti $P$. cannabis, virüsün taşınma ve yayılmasında etkili olmaktadır (Schmidt ve Karl, 1970).

HMV belirtileri bitkilerde çok çeşitlilik gösterebilmekte ve diğer biyotik (virüs, bakteri, viroid) ve abiyotik faktörler ile karıştırılabilmektedir. $\mathrm{Bu}$ nedenle tespiti ve mücadelesi oldukça zordur.

\subsection{Diğer virüsler}

Kenevir bitkilerinde genel olarak yukarıda bahsi geçen beş (HSV, HMV, AMV, CMV, ArMV) viral etmeninin enfeksiyon gerçekleştirdiğ bildirilirken, doğal olarak veya mekaniksel inokulasyon yöntemi ile; tütün mozaik virüsü (TMV), tütün halkalı leke virüsü (TRSV), tütün çizgi virüsü (TSV), domates halkalı leke virüsü (TomRSV), taflan halkalı leke virüsü (ERSV), karaağaç mozaik virüsü (EMV), tilkikuyruğu mozaik virüsü (FMV) gibi çok sayıda virüsün kenevir bitkisini enfekte edebildiği rapor edilmiştir (McPartland ve ark., 2000). Bu virüslerin bir kısmı kenevir bitkilerinde simptomsuz enfeksiyon uluşturduğu indikatör bitkilere geri inokulasyon yöntemi ile belirlenmiştir.

Son yillarda kenevir türlerinde enfeksiyon gerçekleştiren iki yeni virüs ilk kez rapor edilmiștir. ABD/Colorado'da endüstriyel kenevir üretim alanlarında 2015-2019 yılları arasında her üretim sezonu boyunca bitkilerde cüceleşme, yapraklarda sararma, mozayik belirtileri oluştuğu (Şekil 4) ve on gün içerisinde tüm bitkiyi sardığ gözlenmiştir. Yapılan analizler sonucu etmenin şekerpancarı tepe kıvırcıklık virüsü (BCTVCurtovirus, Geminiviridae) olduğu belirlenmiş ve virüsün keneviri enfekte edebildiği ilk kayıt olarak bildirilmiştir (Giladi ve ark., 2020).

İsrail'de izinle kenevir üretimi yapılan alanlarda 2017-2019 yılları arasında yürütülen surveylerde, hastalık belirtisi gösteren kenevir bitkilerine rastlanmıştır. Özellikle yaşl yapraklarda sarılık, kloroz, nekroz belirtisi gösteren örnekler analiz edilmek üzere toplanmıștır (Şekil 5). Yapılan detaylı analizler 


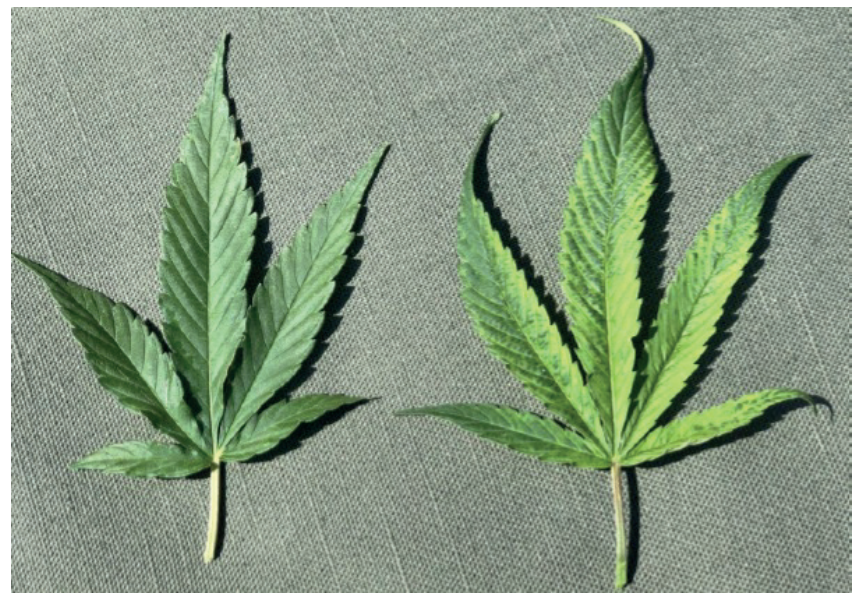

Şekil 4. Sağlıklı bitki yaprağı (solda) ile BTCV ile enfekteli yapră̆ın (sağda) karşıllaştırmalı görüntüsü (Giladi ve ark., 2020)
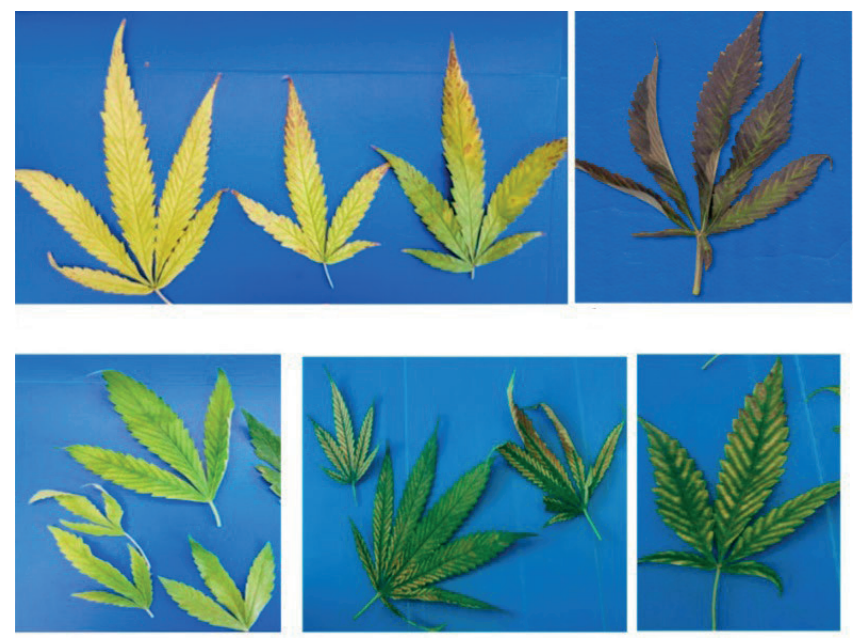

Şekil 5. Arazi örneklerinde gözlenen belirtiler (Yaşlı yapraklarda tamamen sarılık, yaprakta morarma, yapraklarda kloroz, damar aralarında kloroz ve nekroz oluşumu) (Hadad ve ark., 2019)

sonucu etmenin marul kloroz virüsü (LCVCrinivirus Closteroviridae) olduğu tespit edilmiştir. Biyolojik çalışmalarda enfekteli bitkilerde cüceleşme, sürgünlerde kloroz, yapraklarda klorotik lezyonlar meydana getirdiği belirlenmiştir (Şekil 6). Bu çalışmanın kenevir bitkilerinde LCV enfeksiyonu tespiti için ilk kayıt olduğu rapor edilmiştir (Hadad ve ark., 2019).

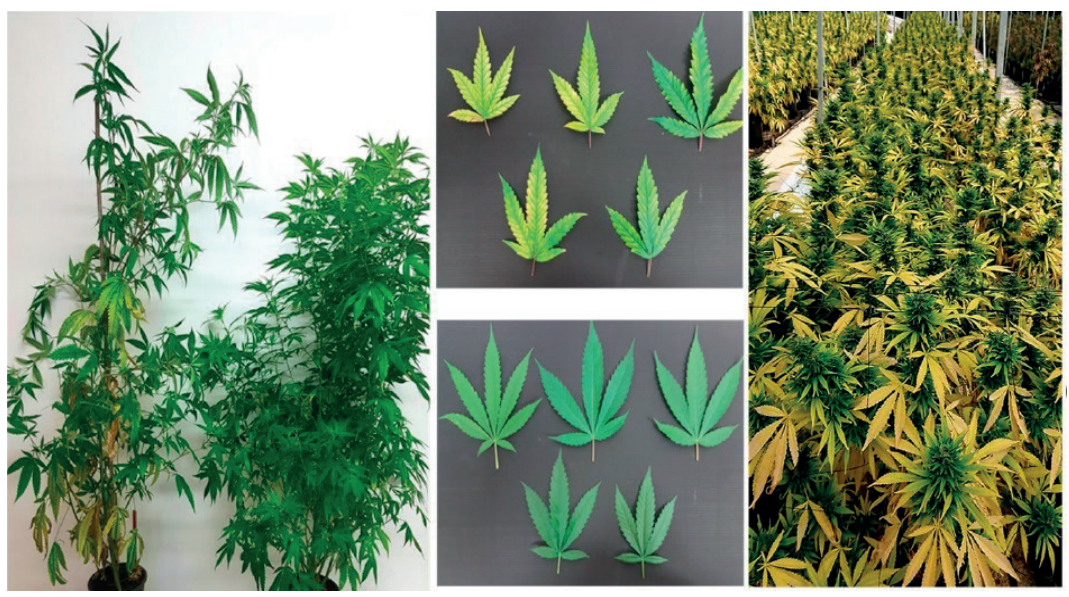

Şekil 6. Biyolojik testler sonucu enfekteli bitkilerde gözlenen bazı belirtiler (Hadad ve ark., 2019) 


\section{Sonuç ve Öneriler}

Bitkilerde yıllık ürün kaybının tahmini \% 13’ünün böceklerden, \% 11'inin hastalıklardan, \% 7'sinin yabanc1 ot ve diğer organizmalardan kaynaklandığ 1 bilinmektedir. Bu nedenle hastalıklar ile mücadele yöntemlerin bilinmesi ve kontrol edilmesi son derece önemli olmaktadır.

Enfekteli bitki artıkları ile zararlılar ve hastalık etmenleri diğer yıla geçebilmektedir. Hasat sonu artıklarının temizlenmesi, sap ve köklerin toplanması son derece önemlidir. Özellikle lif içeren kenevir saplarını parçalama için özel toprak işleme ekipmanları gerektirmektedir. Bitki artıklarının toprak işleme ile derine gömülmesi birçok hastalık ve zararlının ölmesini sağlayabilmektedir.

Keneviri enfekte edebilen virüslerin neredeyse tamamı vektörler (afit, beyazsinek, nematod, vd.) ile taşınabilmektedir. $\mathrm{Bu}$ nedenle vektörlerin üretim alanlara girişi ve yayılmasını önleyici tedbirlerin alınması, virüslerin engellenmesi açısından da oldukça önem arz etmektedir.

Tarımsal üretimde birçok ürünün başlangıç materyali olan tohumun üretim ve çoğaltım aşamasında özellikle virüs hastalıklarına bağlı enfeksiyon oranı artmaktadır. Keneviri enfekte edebilen birçok viral etmen tohum ile tassınabilmektedir. $\mathrm{Bu}$ nedenle kenevir yetiștiriciliğinde kullanılan tohumun sağlıklı olması, hastalık etmenleri ile bulaşık olmaması, enfekteli bitkilerden tohum alınmaması son derece önemlidir.

Birçok bitki virüsüne karş1 sürgün ucumeristem kültürü ile virüsten ari üretim materyali kullanılabilmektedir. Ancak kenevirde bu teknik kullanılması ile ilgili girişimler bulunmamaktadır. Meristem kültürünün yanı sıra termoterapi, kemoterapi vd. tekniklerin de ayrı ayrı veya birlikte kullanılması virüs hastalıkları ile mücadelede başarı oranını arttıracaktır. Yetiştiricilik sırasında kullanılan aletekipmanların, ellerin, giysi ve benzeri eşyaların steril olması gerekmektedir.

Virüse karşı kimyasal mücadele yapılamamakta veya biyolojik mücadele etkisiz kalmaktadır. Ancak kenevir virüs vektörlerine (böcek, nematod) karşı kimyasal (insektisit, nematisit) ve biyolojik mücadele yapılarak virüsün yayılması engellenebilecektir.

\section{Kaynaklar}

Al-Saleh, M.A., Amer, M.A., 2013. Biological and molecular variability of Alfalfa mosaic virus affecting alfalfa crop in Riyadh Region. Plant Pathology Journal, 29(4): 410-417.

Anderson, P.K., Cunningham, A.A., Patel, N.G., Morales, F.J., Epstein, P.R., Dazsak, P., 2004. Emerging infectious diseases of plants: pathogen pollution, climate change and agrotechnology drivers. Trends in Ecology and Evolution, 19(10): 535-544.

Andre, C.M., Hausman, J.F., Guerriero, G., 2016. Cannabis sativa: The plant of the thousand and one molecules. Frontiers in Plant Science, 7(19): 1-17.

Anonymous, 2002. Arabis Mosaic Nepovirus. Data Sheets on Quarantine Pests. EPPO Global Database. (https://gd.eppo.int/taxon/ARMV00/distribution), (E rişim tarihi: 20.12.2019).

Aytac, S., 2018. An environmentally friendly plant in terms of oxygen supply: Hemp. ICOEST 4th International Conference on Environmental Science and Technology, September 19-23, Ukraine, pp. 3134

Aytaç, S., Arslanoğlu, S.F., Ayan, A.K., 2018a. Suçlu olarak bilinen bitki: Kenevir. In: Current Academic Studies Agricultural Sciences, N. Keskin (Ed.) IVPE, Cetinje, Montenegro, pp. 445-455.

Aytaç, S., Arslanoğlu, SF., Ayan, A.K., 2018b. Hightemperature inhibition of seed germination of hemp (Cannabis sp.). Fresenius Environmental Bulletin, 27(12): 8200-8204.

Aytaç, S., Ayan, A.K., Arslanoğlu, S.F., 2017. Endüstriyel tip kenevir (Cannabis sativa L.) yetiștiriciliği. Karadeniz'in Lif Bitkileri Çalıștayı, 56 Mayıs, Samsun, s. 27-35.

Bakro, F., Wielgusz, K., Bunalski, M., Jedryczka, M., 2018. An overview of pathogen and insect threats to fibre and oilseed hemp (Cannabis sativa L.) and methods for their biocontrol. Integrated Control in Oilseed Crops IOBC-WPRS Bulletin, 136(1): 9-20.

Blattny, C., Osvald, C.V., Novak, J., 1950. Virosy a z viros podezrele zjevy u konopi. Ochrana Rostlin, 23: 5-9.

Che, C.T., 1991. Plants as a source of potential antiviral agents. In: H. Wagner, N.R. Farnsworth (Eds.), Economic and Medicinal Plant Research, Academic Press, London, pp. 167-251.

Cherney, J.H., Small, E., 2016. Industrial hemp in North America: production, politics and potential. Agronomy, 6(4): 1-24.

Edwardson, J.R., Christie R.G., 1997. Viruses Infecting Peppers and Other Solanaceous Crops. Gainesville, Florida.

Dingha, B., Sandler, L., Bhowmik, A., Akotsen-Mensah, C., Jackai, L., Gibson, K., Turco, R., 2019. Industrial hemp knowledge and interest among North Carolina organic farmers in the United States. Sustainability, 11(9): 1-17.

Gallitelli, D., 2000. The ecology of cucumber mosaic virus and sustainable agriculture. Virus Research, 71(1-2): 9-12.

Ghani, M., Basit, A., 1975. Investigations on The Natural Enemies of Marijuana, Cannabis satisla L. 
and Opium poppy, Papaver somniferum L. Commonwealth Institute Press, Rawalpindi, Pakistan.

Giladi, Y., Hadad, L., Luria, N., Cranshaw, W., Lachman, O., Dombrovsky, A., 2020. First report of beet curly top virus infecting Cannabis sativa L., in Western Colorado. Plant Disease, 08(19): 16561656.

Gildow, F.E., Shah, D.A., Sackett, W.M., Butzler, T., Nault, B.A., Fleischer, S.J., 2008. Transmission efficiency of Cucumber mosaic virus by aphids associated with virus epidemics in snap bean. Phytopathology, 98(11): 1233-1241.

Gizlenci, S., Acar, M., Yiğen, Ç., Aytaç, S., 2019. Kenevir Tarımı. Tarım ve Orman Bakanlığı, Tarımsal Araştırmalar ve Politikalar Genel Müdürlüğü (TAGEM) Yayınları, Ankara.

Grabowska, L., Rębarz, M., Chudy, M., 2009. Breeding and cultivation of industrial hemp in Poland. Herba Polonica, 55(3): 328-334.

Hadad, L., Luria, N., Smith, E., Sela, N., Lachman, O., Dombrovsky, A., 2019. Lettuce chlorosis virus disease: A new threat to cannabis production. Viruses, 11(9): 1-15.

Hughes, J.D.A., Odu, B.O., 2003. Plant Virology in Sub-Saharan Africa. In: Proceedings of $a$ Conference Organized by IITA. 4-8 June, International Institute of Tropical Agriculture, Ibadan, Nigeria, pp. 581-581.

Hull, R., 2014. Matthew's Plant Virology, Academic Press, USA.

Jaspars, E.M.J., Bos, L., 1980. Alfalfa Mosaic Virus. CMI/AAB Descriptions of Plant Viruses No. 229, CAB International, Wallingford, UK.

Jeffries, C.J., 1998. Technical Guidelines for The Safe Movement of Germplasm: Potato. FAO/IPGRI Publishing, Rome, Italy.

Kegler, H., Spaar, D., 1997. Kurzmitteilung zur Virusanfalligkeit von Hanfsorten (Cannabis sativa L.). Archives Phytopathologie, 30: 457-464.

King, A.M.Q., Adams, M.J., Carstens, E.B., Lefkowitz, E., 2012. Virus Taxonomy: Classification and Nomenclature of Viruses. Elsevier Academic Press, San Diego, California.

Kominek, P., Svoboda, P., Abou Ghanem-Sabanadzovic, N., 2003. Improved detection of Arabis mosaic virus in grapevine and hop plants. Acta Virologica, 47(3): 199-200.

Kumari, R., Bhardwaj, P., Singh, L., Zaidi, A.A., Hallan, V., 2013. Biological and molecular characterization of cucumber mosaic virus Subgroup II Isolate causing severe mosaic in cucumber. Indian Journal of Virology, 24(1): 27-34.

Lancz, G., Specter, S., Brown, H.K., 1990. Suppressive effect of delta-9-tetrahydrocannabinol on herpes simplex virus infectivity in ilitro. Proceedings of the Society for Experimental Biology and Medicine, 196(4): 401-404.
McPartland, J.M., 1996. A review of Cannabis diseases. Journal of The International Hemp Association, 3(1): 19-23.

McPartland, J.M., Clarke, R.C., Watson, D.P., 2000. Hemp Diseases and Pests: Management and Biological Control. New York: CABI Publishing.

Ouedraogo, R.S., Pita, J.S., Somda, I.P., Traore, O., Roossinck, M.J., 2019. Impact of cultivated hosts on the recombination of Cucumber mosaic virus. Journal of Virology, 93(7): e01770-18.

Palukaitis, P., García-Arenal, F., 2003. Cucumoviruses. Advances in Virus Research, 62: 241-323.

Palukaitis, P., Roossinck, M.J., Dietzgen, R.G., Francki, R.I.B., 1992. Cucumber mosaic virus. Advances in Virus Research, 41: 281-348.

Parrella, G., 2000. Evidence for two distinct subgroups of Alfalfa mosaic virus (AMV) from France and Italy and their relationships with other AMV strains. Archives of Virology, 145(12): 2659-2667.

Ranalli, P., 1999. Advances in Hemp Research. The Haworth Press, Binghamton, New York.

Righetti, L., Paris, R., Ratti, C., Calassanzio, M., Onofri, C., Calzolari, D., Menzel, W., Knierim, D., Magagnini, G., Pacifico, D., Grassi, G., 2018. Not the one, but the only one: About cannabis cryptic virus in plants showing 'hemp streak' disease symptoms. European Journal of Plant Pathology, 150(3): 575-588.

Salentijn, E.M., Zhang, Q., Amaducci, S., Yang, M., Trindade, L.M., 2015. New developments in fiber hemp (Cannabis sativa L.) breeding. Industrial Crops and Products, 68: 32-41.

Schmelzer, K., 1963. Investigations on viruses of ornamental and wild woody plants. Phytopathologische Zeitschrift, 46: 105-138.

Schmidt, H.E., Karl, E., 1969. Untersuchungen über eine Flecken- und Streifenbildung am Hanf (Cannabis sativa L.). Zweite Abteilung, 123: 310-314.

Schmidt, H.E., Karl, E., 1970. Analysis of the viruses of hemp (Cannabis sativa L.) with regard to the hemp aphid (Phorodon cannabis Pass.) as virus vector. Zentralblatt Bakteriologie, Parasitenkunden, Infektionskrankheiten Hygiene, 125(1): 16-22.

Scholthof, K.B.G., Adkins, S., Czosnek, H., Palukaitis, P., Jacquot, E., Hohn, T., Hemenway, C., 2011. Top 10 plant viruses in molecular plant pathology. Molecular Plant Pathology, 12(9): 938-954.

Soosaar, J.L., Burch-Smith, T.M., Dinesh-Kumar, S.P., 2005. Mechanisms of plant resistance to viruses. Nature Reviews Microbiology, 3(10): 789-798.

Thresh, J.M., Ormerod, P., 1989. Arabis mosaic virus in English hop plantings. In: Proceedings of the International Workshop on Hop Virus Diseases, A. Eppler (Ed.), December 8, Deutsche Phytomedizinische Gesellscaft, Ulmer Verlag, Stuttgart, Germany, pp. 43-54.

Whitfield, A.E., Falk, B.W., Rotenberg, D., 2015. Insect vector-mediated transmission of plant viruses. Virology, 479: 278-289. 
ŞEVIK

Xu, H., Nie, J., 2006. Identification, characterization and molecular detection of Alfalfa mosaic virus in potato. Phytopathology, 96(11): 1237-1242.
Zitter, T.A., Murphy, J.F., 2009. Cucumber mosaic virus. The Plant Health Instructor. APS Press, St Paul, MN. 